\title{
Contemporary Legal Issues of Ensuring Food Security in the Post-Soviet Space (in Terms of Russia)
}

Aleksey Pavlovich Anisimov, Nina Vladimirovna Mirina, Anatoliy Jakovlevich Ryzhenkov

The article deals with theory and practice of ensuring food security in the Russian Federation in the context of the UN recommendations and achievements of legal thought of foreign countries. Food security is considered as a guarantee of sustainable development of agriculture located at the junction of three types of national security: economic, social and environmental. The authors prove the need to distinguish between the categories "food security" and "food independence", arguing in favor of giving preference, at the national level, to the human right to food through both production of domestic agricultural goods and their import from other countries. Stating the consequences of the food sanctions imposed by Russia against other countries which are negative for itself, the authors propose their lifting with the suggested complex of measures to develop Russian agriculture.

Keywords: food security, climate, GMOs, right to food, UN.

\section{Introduction}

The legal category "food security" is directly connected with such human rights as the right to adequate nutrition and the right to life without hunger in compliance with the International Covenant on Eco-

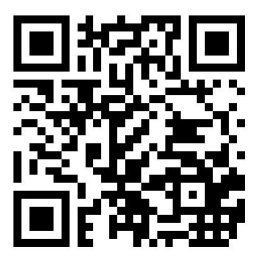

\footnotetext{
Aleksey Pavlovich Anisimov, Nina Vladimirovna Mirina, Anatoliy Jakovlevich Ryzhenkov. Contemporary Legal Issues of Ensuring Food Security in the PostSoviet Space (in Terms of Russia). Central European Journal of International and Security Studies I4, no. I: I06-I3I.
}

(c) 2020 CEJISS. Article is distributed under Open Access licence: Attribution NonCommercial 3.0 Unported (cc by-nc 3.0). 
nomic, Social and Cultural Rights, I966, as well as other documents of the UN. The human right to nutrition provides a clear basis for defining legal duties of states and other subjects in terms of the fight against global hunger and is a means of ensuring compliance with these duties, both at the national and international levels ${ }^{\mathrm{I}}$. The category "food security" is closely related to the issue of ensuring social justice, which implies development of appropriate measures at the national and international levels, adjustment of economic, environmental and social policies of national governments'. Emergence of the term "food security" was caused by the grain crisis of I972-I973, when overproduction of food in developed countries went hand in hand with hunger in the third world countries. It was then that the issue of food security went beyond national borders and was discussed by the world community for the first time3. In December 1974, the UN General Assembly endorsed the International Commitments on Food Security in the World developed by the Food and Agriculture Organization (FAO) of the UN, which already mentioned a number of important definitions of a general nature ${ }^{4}$.

Exactly from this moment (although the task of ensuring food security is entrusted to national governments), we can observe the increase of the coordinating role of the UN (especially the FAO), which is aimed at development of a common strategy to solve this issue. This issue is solved both due to framework agreements aimed at implementation of the sustainable development strategy and through development of more specific measures dedicated to certain areas of ensuring food security, for example, of women, children or other social groups. A situation where in the future no one will suffer from hunger or insufficient food is perfect from the point of view of the UN. For this purpose, it is necessary to provide all people on the Earth with permanent access to the necessary amount of food, which will require increase of its production through technological breakthroughs, adequate financing, reduction of food losses and other necessary measures. However, at the moment achievement of these goals remains a long-term perspective.

As noted in the UN General Assembly Resolution of December I9, 20I7, "The right to food", up to 45 per cent of the total number of children who die every year before the age of 5 die from malnutrition and hunger-related illness. In addition, according to the FAO estimates, about 8I5 million people in the world suffer from chronic undernu-
Aleksey Pavlovich

Anisimov

Nina

Vladimirovna

Mirina

Anatoliy

Jakovlevich

Ryzhenkov 
trition owing to the lack of sufficient food for the conduct of an active and healthy life.

The current situation is a direct consequence of failure to accomplish the tasks of food security, although the Earth could produce

CEJISS

I/2O2O enough food to feed all its inhabitants.

In this regard, it is necessary to intensify the efforts of all states of the world, including their local government bodies and civil society institutions, to develop a new food security strategy based on the UN recommendations, but at the same time taking into account the national specific character of a particular country. To ensure adequate nutrition, it will be necessary to create sustainable and sustainably developing, balanced food systems in each country of the world.

One of the elements of such sustainability is due attention of governments to issues of rational use of natural resources and environmental protection, the relevance of which increases significantly under current conditions of global climate change. Settlement of these issues returns the questions about the role of GMOs in securing the right to food and food security, as well as reasonability of adopting the concepts of "food sovereignty that replace the task of providing food to the population" in individual states of the world (including Russia), to the agenda of international and national discussions.

From this perspective, in the first part of this article we will consider the role of international public law in coordination of the efforts of national states (in terms of Russia) in ensuring food security, including the prospects of this influence on the content of national legal acts; in the second part we will analyze Russian and international discussions about the concept and components of the concept of food security. Finally, in the third part of our article we will give a number of recommendations for adjusting the food strategy in Russia.

\section{International legal regulation of ensuring food security and its influence on national law}

Several dozens of international instruments having different legal force and adopted in different years, including within the UN framework, are dedicated to issues of ensuring food security in some or other contexts. In its most general form this list should include the Universal Declaration of Human Rights of I948, which implies that every person has the right to such a standard of living that is necessary to maintain his or her health and well-being, including food; the Universal Declaration 
on the Eradication of Hunger and Malnutrition; the 2030 Agenda for Sustainable Development, which stipulates widespread elimination of hunger, ensuring food security, improvement of nutrition and promotion of sustainable development of agriculture. Provisions of the International Covenant on Economic, Social and Cultural Rights, the Rome Declaration on Nutrition and the Framework for Action adopted in Rome on November 2I, 2014 also has had a significant influence on development of the international legal concept of food security. This list of international instruments is not exhaustive; however, it allows formulating several theses on the main areas of ensuring food security at the international level.

First of all, attention should be paid to the interconnection of the task of ensuring food security and exercise of human rights, mainly, the right to food, which is constantly underlined by the $\mathrm{UN}$, as well as addressing food security issues in the context of sustainable development. Within the framework of the first approach, attention is paid to the fact that the right to food is the right of every individual, alone or in community with others, to have physical and economic access at all times to sufficient, adequate, nutritious food, in conformity with, inter alia, the culture, beliefs, traditions, dietary habits and preferences of individuals, that is produced and consumed sustainably, thereby preserving access to food for future generations ${ }^{5}$. Within the framework of the second approach, social, economic and environmental components of food security are underlined in the international documents ${ }^{6}$.

Declaration in a number of the UN documents of the necessity to eradicate extreme poverty by 2030 is one of manifestations of the recent trend, so that all people of the Earth could exercise the right to a basic standard of living due to the success of the fight against hunger and malnutrition. In this regard, it is proposed to devote resources to developing rural areas and sustainable agriculture and fisheries, supporting smallholder farmers, especially women farmers, herders and fishers in developing countries, particularly least developed countries ${ }^{7}$.

Despite the fact that it is the states that have primary responsibility for their national food security, the UN documents quite clearly regulate the mechanism of guarantees of exercise of the human right to food, including recommendations for states to refrain from applying any unilateral economic, financial and trade measures not in accordance with international law and the Charter of the United Nations that impede the full achievement of economic and social devel-
Food Security in the Post-Soviet Space 
opment, to eliminate and prevent introduction of trade restrictions and emergence of distortions in world agricultural markets.

The work of the FAO on creation of a trust fund for providing support to measures in the area of nutrition aimed at promotion of the CEJISS efforts of governments to fulfill the assumed obligations is equally I/2020 important. This fund will become the main tool for distribution of non-target and partially target contributions. It will help to perform mobilization of resources for the needs of state programs aimed at creation of favorable conditions for improving nutrition, introduction of sustainable food systems ensuring a healthy diet, as well as to promote attraction of investments and development of trade with the purpose of improving the quality of nutrition, etc. Along with financial guarantees, there is also work on development of organizational guarantees aimed at implementing subparagraph "o" of paragraph I4 of the Rome Declaration on Nutrition and intended to make the Committee on World Food Security the main intergovernmental multilateral global forum on nutrition issues.

Therefore, only collective efforts of all countries of the world will make it possible to eliminate root causes of lack of food security and malnutrition, in particular, poverty, inequality and lack of access to resources and the possibility to carry out income-generating activities.

This is important since it becomes increasingly difficult for many current food systems to provide citizens with sufficient, safe, diverse, and nutrient-rich foods ensuring a healthy diet because of restraints caused by the resource shortage and deterioration of the state of environment, as well as unsustainable production and consumption patterns, food loss and food waste. Unfortunately, in a number of countries of the post-Soviet space the emphasis is placed not on provision of citizens with the necessary amount of high-quality and safe food but on the formal aspect associated with establishment of the percentage of food produced directly in this country. For example, in the Republic of Kazakhstan, food security is considered achieved if consumers are provided with domestic food in the amount of at least $80 \%$ of annual consumption with consideration of the social and demographic structure of the population, traditional peculiarities, etc 8 .

In Russia, the Doctrine of Food Security of the Russian Federation of 2010 proposes to determine, as a criterion for assessment of the state of food security, the proportion of domestic agricultural, fishery products and food in the total volume of commodity resources of the 
domestic market of the corresponding products, and this proportion has the following threshold values: grain - minimum 95\%, sugar minimum $80 \%$; vegetable oil - minimum $80 \%$; meat and meat products (in meat equivalent) - minimum $85 \%$; milk and dairy products (in milk equivalent) - minimum $90 \%$; fish products - minimum $80 \%$; potatoes - minimum 95\%; edible salt - minimum 85\%. In this Doctrine, we can clearly trace the thought about the need to gradually reduce the "dependence of the domestic agro-industrial and fisheries complexes" on the import of technology, machinery, equipment and other resources, including food.

Therefore, the Doctrine places the main emphasis in achieving the goals and objectives of food security not on quantity and quality of food, not on development of trade and international cooperation, but on consideration of self-produced quantity of food calculated as a percentage of the total amount of food available in the country.

The discrepancy between the goals and objectives of food security declared by the UN and implemented in Russia has clear doctrinal ground resulting from many years of discussions. For example, some authors note that adoption of this Doctrine means the beginning of a new stage in the life of the country, "food self-sufficiency", and approve this 9 . Other supporters of this concept use a somehow different term mentioned in the Doctrine itself, "food independence"

Followers of this concept, speaking about the need for self-sufficiency of the country in relation to the main types of domestic food, believe that decline of domestic production is a sign of a threat to or even loss of food security, and they require to strengthen support measures for Russian agricultural goods producers by limiting the possibility of food import ${ }^{\mathrm{II}}$. Therefore, supporters of this theory do not make a clear distinction between the categories "food security" and "food independence". At the same time, this group of scholars notes a number of differences between, first, nations that have the possibility to feed their people by any means, and, second, nations that have the possibility to feed their people with the use of their own resources. A country that can feed its people under any external impact will have sufficient stability to act with maximum independence. Such a state is difficult to intimidate or coerce from abroad. However, a number of countries in the world already suffer from lack of food security (Madagascar). ${ }^{12,13}$

Supporters of the concept of "self-reliance" are opposed by the views of opponents who understand food security as general security of the
Aleksey Pavlovich

Anisimov

Nina

Vladimirovna

Mirina

Anatoliy

Jakovlevich

Ryzhenkov 
domestic food market implying the ability of the state to provide its population with a sufficient amount of safe food not only on the basis of national production but also with active use of advantages of international trade. In terms of this approach the issue of food security CEJISS comes down only to filling the food market, without setting a goal to I/202O limit external supplies of food products. Accordingly, the key objective must be to provide the population with food both with the use of domestic resources and import deliveries (in case of lack of the necessary production volumes in the domestic market). Therefore, on the one hand, the country must develop foreign economic cooperation in this area, and, on the other hand, within the framework of food security, give preference to domestic producers ${ }^{14}$.

We share the latter approach based on rules of international law and the UN recommendations, and we believe that the best guarantee of international trade and food supplies will be the country's peaceful policy. Russia has to legislate a direct connection between food security and the right to food (within the spirit of the UN resolutions) and shift the focus from the goal of complete food self-sufficiency at any price towards saturating the domestic market with high-quality and healthy food, both of own production and imported from other countries, with establishing guarantees of the right to food for vulnerable groups of population. All this does not impede development of national agriculture of Russia at all and does not exclude continuation of these discussions.

\section{Discussions on ways to ensure food security and their applicability for Russia}

2.I. Concept and components of food security

At the moment in legal science of countries of the post-Soviet space there are still discussions on what exactly should be understood as "food security" and which role it has in the system of related legal categories, including the category "economic security".

Initially the concept "food security" was enshrined in the Model Law of October I6, 1999 "On Food Security", which was adopted by the Inter-Parliamentary Assembly of the Member States of the Commonwealth of Independent States (CIS), in which national food security is defined as a state of economy that ensures food independence of a country and guarantees physical and economic availability of food for the entire population in the amount necessary for an active and 
healthy life. Afterwards this definition of "food security" was expanded by Decree of the President of the Russian Federation of January 30, 2010 No. I20 "On Approval of the Doctrine of Food Security of the Russian Federation", according to which "food security of the Russian Federation is a state of the country's economy that ensures food independence of the Russian Federation, guarantees physical and economic availability of foods complying with the requirements of the legislation of the Russian Federation on technical regulation for every citizen of the country, in the amount that is not less than rational norms of consumption of foods necessary for an active and healthy lifestyle".

Therefore, in both of the official documents the main emphasis is placed on "food independence", that is the ability of the state to independently provide itself with products, and the second aim is availability, quantity and quality of food. The existing doctrinal definitions either reproduce in whole or in part this official definition or propose particular additions thereto.

For example, within the first approach, V. V. Demyanenko believes that "food security" is such a state of economy that guarantees physical and economic availability of food for the entire population in the amount necessary for an active and healthy life ${ }^{15}$.

Within the second approach, a number of additions and specifications is proposed for the official definition. For example, the first group of scholars believe that food security is "the ability of a state to guarantee satisfaction of needs for high-quality ecologically clean food at such a level at which normal living of the entire population is provided on a national scale" ${ }^{\text {"16 }}$. Therefore, this "environmental" approach pays special attention to issues of quality and safety of food, which seems quite reasonable in terms of the need to reduce the negative impact of waste of agricultural production on nature and pollution of air, soil and water bodies by its products ${ }^{17,18}$.

Other its followers pay attention to the need for additional consideration of "food culture" of peoples of the Russian Federation ${ }^{\text {19 }}$ (thus going beyond the Doctrine and borrowing the recommendations given in the UN resolutions), or in addition to "physical and economic availability" mention "social access to high-quality and safe foods" We should separately mention the point of view analyzing "the state of the international community being protected from threats associated with the lack of physical and economic access to a sufficient amount of safe food aimed at ensuring sustainable development ${ }^{{ }^{21}, 22}$. Therefore,
Food Security in the Post-Soviet Space 
there is a traditional set of components of food security (physical, economic access, safety of food), but at the same time its aim is highlighted - ensuring sustainable development, which is uncommon.

In the course of discussion of the question about the concept of CEJISS food security, the question about its "levels" often arises. Some authors $\mathrm{I} / 2020$ consider food security as a hierarchical system, which is divided by subject into global, national, regional and household food security. At the same time, they argue in favor of the conclusion that improvement of the food policy should be aimed at strengthening the economic independence of subjects of the Russian Federation with shifting the center of gravity in solving food issues to their level ${ }^{23}$.

L. N. Deineka distinguishes another list of food security levels: world (global), mega-regional, national, regional and at the level of an individual person, family, social group ${ }^{24}$. V.A. Dadalko distinguishes the following food security levels: individual (of person); localized (of household); local (of city, district, municipal entity, free economic zone, biosphere territory); territorial (of region); regional (of two and more subjects of state formation); national (of state) $)^{25}$. Fully agreeing that in a federal state the subjects of the federation should participate in solving food security issues much more actively (than now), yet it should be noted that, based on international recommendations of the $\mathrm{UN}$ and the established national practice, distinguishing the "lower level" of food security (of person, family, social group) is not reasonable, since food provision of individual citizens is only a consequence of the food policy of the state and the international community. Distinguishing the local level is also debatable due to the limited ability of the Russian municipalities to influence the food policy. In addition, the purpose of distinguishing the "biosphere territory", where wildlife is present, is not clear at all. It will be more reasonable to be limited to distinguishing three levels: international, national and regional.

There is also no unanimity of opinion regarding the issue of the role of food security in the system of other types of national security. For example, legal scholars of Kazakhstan suppose that food security is a part of economic security ${ }^{26}$. Many Russian scholars share this opinion too ${ }^{27}$. At the same time, other Russian scholars note that food security, on the one hand, is a "subsystem" in the system of economic and national security, and, on the other hand, it has its own scope and integrity. This is why food security is understood as provision, resistant to negative internal and external impact, of the entire pop- 
ulation with food in the required amount, with the necessary range and quality ${ }^{28}$.

Therefore, food security is an independent variety of national security located at the junction of economic, environmental and social security. Like it is unacceptable to overestimate the significance of the environmental factor (although Russian scholars do this) within the framework of the concept of sustainable development ${ }^{29,} 3^{30}$, the economic factor must not be given priority in the concept of food security. All the components of this security given above are important in their own way. Implementation of the concept of food security involves physical and economic access of population of a country (taking into account the regional peculiar features of consumed products) to high-quality foods available in the necessary amount, which is one of the requirements for the country's transition to implementation of the concept of sustainable development. We strongly believe that the main emphasis in implementation of the concept of food security must be placed exactly on this but not on the amount of goods produced by the country itself outside the context of their quality, which does not exclude the need for development of own agrarian production, system of trade, creation of reserves, etc.

\subsection{Influence of global climate change on ensuring food security}

The effects of global climate change are often discussed both in the UN and by legal scholars ${ }^{31,32,33}$, and this issue is directly related to issues of ensuring food security. Agriculture, one of the main sources of anthropogenic greenhouse gas emissions, contributes to climate change, and climate change threatens global food production, increasing frequency and severity of droughts, floods and hurricanes, reducing crop yields and imposing additional load on limited water resources ${ }^{34}$. Today production of goods in agriculture remains an underestimated and poorly understood aspect of the issue of global climate change, though it is noted that work of tractors, trucks, use of fertilizers, production of electricity in agriculture make up to $9 \%$ of the total contribution to climate change from the point of view of $\mathrm{CO}_{2}$ emissions, though as a percentage of all global greenhouse gas emissions, direct $\mathrm{CO}_{2}$ emissions from exactly agricultural activity are only about $\mathrm{I} .4 \%{ }^{35}$.

It is no coincidence that par. 8 of the Rome Declaration of the UN on Nutrition of $2014^{36}$ recognizes the need to respond to the effects of climate change and other environmental factors affecting food se- 
curity and nutrition, especially the quantity, quality and diversity of produced food, by taking appropriate measures to eliminate adverse effects. Climate change is the biggest threat to developing countries, where persistent droughts and extreme weather events, land degraCEJISS dation, sea level rise, coastal erosion, ocean acidification and retreat I/202O of mountain glaciers pose a greater threat to food security than in developed countries and undermine the efforts aimed at poverty eradication and sustainable development ${ }^{37}$. This is why adoption of measures to mitigate effects of climate change and adapt to them is one of the most urgent global priorities for all countries of the world including Russia.

In this regard, all countries of the world will have to make efforts to support application of agricultural methods with consideration of climatic factors, including agroforestry, conservation farming, water saving, use of drought-resistant and moisture-resistant varieties of plants and rational animal husbandry, and to establish and strengthen relations among scholars, legislative bodies, entrepreneurs and those who finance science, technology and innovation, as well as to take measures to increase resilience of vulnerable groups and food systems, paying special attention to adaptation to climate change as one of the main issues and tasks facing all farmers and food producers including small $\mathrm{farms}^{38}$. At the national level, attention should be paid to protection of rights of indigenous peoples (for example, Indians), whose traditional lifestyle is affected by climate change ${ }^{39}$.

The main issue here is that, first, it is impossible to recover damages caused to agricultural production due to climate change (draughts, floods) because it is difficult to prove the causal relationships between activity of an industrial facility producing greenhouse gas emissions and an occurring natural disaster. The existing judicial practice in the USA does not recognize this dependence ${ }^{40,4 \mathrm{I}}$. There is no such judicial practice in Russia and all other countries of the CIS at all. In world science, it is noted that global climate change leaves two main survival strategies to mankind: a strategy of adapting to climate change and a strategy of mitigating such effects. "Climate mitigation" is the result of anthropogenic intervention aimed at reducing sources or decreasing greenhouse gas emissions.

In its turn, "adaptation" is a regulator of natural or social systems in response to actual or expected climate change or its effects, which mitigate harm or provide new beneficial opportunities. Measures to 
mitigate effects of climate change are often preventive because they address the sources of climate change, while adaptation is created as a measure to respond to effects of an already changed climate. A number of climate change mitigation options can be identified: energy production with less greenhouse gas emissions than traditional fossil fuel; technologies for removing greenhouse gases from the atmosphere; land use, agriculture and forestry methods that reduce greenhouse gases in the atmosphere ${ }^{42}$.

In its turn, the strategy of adapting to adverse effects of climate change may manifest itself in award of grants by the state for breeding of new drought-resistant plant varieties; subsidizing installation of new irrigation systems (for example, drip irrigation); development of new pest control products and new technologies for combating soil salinization; acclimatization of new species of flora and fauna; introduction of new economic models of employment of population affected by drought. Moreover, it is necessary to create a mechanism of protection of rights of environmental refugees, develop the healthcare system due to emergence of new diseases, etc.

However, implementation of these strategies, for example, for Russia is complicated by two groups of factors. First, the environmental legislation of Russia (in contrast to, for example, Kazakhstan) does not know such an object of protection as climate. Accordingly, measures to mitigate or adapt agriculture to effects of global climate change can not be developed. Second, the strategy of "self-reliance" excludes the possibility of establishing international cooperation, winning international grants for research and its joint implementation with members of the scientific community of other countries. Meanwhile, we should note that, though the effects of global climate change for agriculture of Russia are regularly studied by the leading Russian research centers (Moscow State University, RANEPA and other ones), their results are extremely poorly used by public authorities of all levels when adopting management decisions aimed at ensuring sustainable development of Russian agriculture.

\subsection{Ensuring food security in the context of discussions on production of goods using GMOs}

According to experts, in order to feed the world's population, the number of which will reach 9.I billion people by 2050 , it will be necessary to increase production of agricultural goods by $70 \%{ }^{43}, 44$. One of possible
Food Security in the Post-Soviet Space 
ways to solve this issue is to use the latest biotechnologies, the most famous of which using GMO technology. Today development of this type of technology is the subject of fierce and lengthy discussions. All scholars, regardless of science, express their concern about safety of

CEJISS GMO technology. For example, many Russian doctors do not exclude $\mathrm{I} / 2020$ the possibility of growth of diseases of the digestive system in Russia not only because of poor-quality food but also as a result of increased consumption of products manufactured using $\mathrm{GMOs}^{45}$. Other scholars worry about harmfulness and danger of using transgenic organisms in agriculture and food industry. Genetically modified food has a new combination of genetic material obtained by methods unusual for breeding methods; the consequences of human consumption of such food are unpredictable, which requires production of ecologically clean products ${ }^{46}$.

It is also stated in official documents. For example, the Doctrine mentioned above several times refers to the need to exclude uncontrolled distribution of food products manufactured from genetically modified plants using genetically modified microorganisms and microorganisms having GM analogues (par. I2).

In Russia (as in many other countries of the world), commercial production of agricultural goods using GMO technology is prohibited (though research is allowed), which is substantiated by its potential threat for the future mankind. Another point of view is that biotechnologies are an effective means to protect people from hunger and diseases. Today about two dozen transgenic plant cultures are grown in the USA, Canada, China and other countries: potatoes and corn resistant to insect pests, varieties of vegetables and fruits with an extended shelf life, soybean resistant to herbicide for weed control. They have developed a variety of rise that is genetically improved due to beta-keratin, which turns into vitamin A in the body, as well as another transgenic modification of rice characterized by an increased iron content. Their lack in the body can cause mental retardation, blindness, and even death, and genetically modified rice helps to deal with the problem of the deficiency of these trace elements. However, the long-term effects of consumption of such products are still little studied. Danger of GM foods is often associated with a negative influence on the environment. It is assumed that a transgenic crop may be unsuitable for local bees, or, on the contrary, attractive for a particular type of caterpillars, they can multiply and upset the balance of the ecosystem. 
In a number of countries of the world, genetically modified foods are prohibited or there are requirements for mandatory indication of their presence among ingredients of products. This is why the EU countries are very cautious about genetic engineering and impose bans on the food that can cause adverse effects for human health. In the USA, there are also some restrictions, but they arise only when harm to health is proven in court ${ }^{47}$.

According to many experts, influence of the majority of types of GMOs on ecosystem processes is of an indirect nature, it is the result of changes in the management strategy but not a consequence of direct impact of GMOs. In this regard, there is an urgent need to conduct fundamental environmental and agronomic research to study impact of GMOs on ecosystem processes in order to assess such possible impact. It is this knowledge gap that lies between European cautious and American biotechnological approaches to regulation of use of GMOs in production of agricultural $\mathrm{crops}^{48}$.

Fully supporting the idea of the need for additional research on effects of using GMOs in agriculture, let us express a number of constructive considerations.

I. In order to feed mankind, which continues increasing, on the available (or even reducing) agricultural lands, it is necessary to make a technological breakthrough allowing gathering more crops from the same areas. Other options can be connected only with expansion of tillage due to natural ecosystems, including through deforestation. Today the scientific community does not offer other options for increasing yields besides use of GMO technology. Prohibition of GM foods in a number of countries does not have any scientific basis and may be due to the purpose of fighting more successful competitors.

2. All officially registered cases of harm caused to health of citizens or nature took place not because of the use of achievements of genetic engineering as such but because certain companies producing agricultural genetically modified foods applied the corresponding technology in a wrong way. Accordingly, genetic engineering is a manifestation of scientific and technological progress that cannot be prohibited. Regulation of use of genetic engineering technologies should, in our view, be considered in the context of the balance of private and public interests, the purpose of which is to find a compromise rather than general
Aleksey Pavlovich

Anisimov

Nina

Vladimirovna

Mirina

Anatoliy

Jakovlevich

Ryzhenkov 
prohibition of all modern technologies of genetic engineering. This is why instead of banning GMOs, it is more reasonable to develop internationally recognized rules and regulations for management of GMOs, which should respect the interests of the business using genetic engineering technologies in agricultural production and society at the same time without exposing human health and the state of the environment at real or potential risks.

3. Lands under cultivation constantly reduced during the last years of reforms in Russia. Thus, in order to solve the food issue in Russia, there is no need to develop new areas that have not been used as arable before upsetting the natural ecological balance. It is sufficient to use lands previously used for agricultural production in the coming years. This will allow providing the market with ecologically clean products, which, in contrast to agricultural products containing GMOs, have a much higher price. Therefore, today it makes no sense to ban production and consumption of products containing GMOs in Russia - economic prerequisites should be created for growing and consuming ecologically clean products (there is objectively everything necessary for it), which will allow making a significant contribution to ensuring food security.

\section{Ways to enhance legal regulation of ensuring food security in terms of Russia}

At the moment, at the regulatory and law enforcement levels, Russia implements a concept within the framework of which the main purpose of ensuring food security is production of agricultural goods using domestic capacities, with prohibition or restriction of food supplies from some other countries.

This approach can be found in Decree of the President of the Russian Federation of August 6, 20I4, No. 560 "On the Introduction of Certain Special Economic Measures in the Interest of Ensuring the Security of the Russian Federation" (as amended on July I2, 2018), which contains an order for the Government of Russia to make a list of foreign goods the country of origin of which is the USA, the European Union countries, Canada, Australia and the Kingdom of Norway, and establish restrictions on foreign economic operations on them as a measure in response to sanctions imposed on Russia after the annex- 
ation of the Crimea. It was assumed that such measures could provide import substitution by means of increasing production of Russian agricultural goods, raw materials and foodstuffs, which would support agricultural goods producers of the Russian Federation. In pursuance of this Decree, the Government specified a list of prohibited imported products, which included poultry and cattle, pork, fish and other seafood, milk, dairy products, vegetables, fruit, nuts, sausages, cheese. Attempts of members of civil society to appeal against these legal acts with the Supreme Court of the Russian Federation did not result in success, since the consumer protection legislation does not provide for their right to contest regulatory acts, especially if they are not subjects of the relations to which they apply ${ }^{4}$.

Here, two questions arise: first, if the countersanctions imposed by the Russian authorities against foreign goods producers were effective, and, second, what measures to ensure food security of Russia in the context of the UN recommendations must look like.

Answering the first question, we should note that introduction of a ban on the import of food from a number of leading European countries and the USA (without any transitional period) led to several consequences. First, since the beginning of 2014 food prices have increased in the country by $14.9 \%$ on average. As the reasons for the growth of prices, we should mention the weakening of the ruble and the cost increase leading to the higher transportation cost and customs duties, as well as lack of competition and monopolies in the food market. As a result, in 20I4-2016 the share of expenses on foodstuffs in the structure of expenses for end consumption of households grew from 28.5 to $33.5 \%$ on a national average, and this share exceeds $40 \%$ in the rural area. In most Russian regions, the share of expenses on food in the aggregate expenses for end consumption of population comprises from 35 to $50 \%{ }^{50}$.

Second, the restrictions on import of products to Russia from a number of foreign countries did not strengthen the positions of domestic agricultural producers. As a result, there was just a redistribution of import flows: now Russia buys products not in Europe, but in Turkey, Argentina and Brazil. And if sanctions were imposed against Europe, then new quotas for supply of meat and vegetables were opened for Brazil ${ }^{\text {II }}$. In addition, the quality of the products coming to Russian markets from such countries is not always high ${ }^{52}$. Moreover, no matter what the volume of investments in Russian agriculture is,
Food Security in the Post-Soviet Space 
the situation will not change quickly. There is a natural, biological cycle: in order for gardens to appear, they must first be laid out, and only in 4-5 years it will be possible to harvest apricots, plums and so on. As a result, in 2015 the share of the aggregate import from countries of

CEJISS Latin America exceeded the share of the EU countries, the main partI/2020 ners of Russia before: in 20I4, import from these countries amounted to $19.3 \%$ and $29.5 \%$, respectively ${ }^{53}$.

Third, there is information that, instead of high-quality European and American agricultural products, the market received low-quality Russian and foreign products (for example, milk) made using palm oil (import of which to Russia, after the Government of the Russian Federation introduced "countersanctions", for example, only in January November 2018 increased by $24 \%$ compared to the same period last year) ${ }^{54}$. Meanwhile, there is noteworthy data about harm of palm oil to human health ${ }^{55}$. As a result, this is one of the reasons why an increase in the incidence of diseases among the population is registered in Russia.

Fourth, the decision of the Russian authorities to destroy "sanctioned" products caused an ambiguous reaction of the population. One part of it adheres to the point of view that the Russian Federation, to the full extent, has the possibility to provide its population with all the necessary foodstuffs without involving supplies from abroad. Another part is an obvious opponent of disposal of foodstuffs, as burning products is a real crime, especially in a country where a sufficiently large part of the population is hungry and lives below the poverty line. For example, according to a sociological survey, which was conducted by Levada-Center, about half of the citizens of Russia are opponents of destroying sanctioned products ${ }^{56}$ that could be transferred to orphanages, the army, schools, etc.

Fifth, there has been no "rapid growth" of Russian agricultural production. For example, according to official statistics, in 2017 all farms collected 21708 thousand tons of potatoes, or $96.6 \%$ of the level of $2016 ; 2682$ thousand tons of fruit and berries, or $87.8 \%$ of the level of $2010^{57}$. The gross yield of agricultural crops in farms of all categories also notably decreased in 2017 (for example, in the Central Federal District $87.8 \%$ of the yield in 2016). Cattle production in 2017 comprised $98.6 \%$ of 2016 , though there is a slight increase in milk production (IOI.3\% of 20I6) $)^{8}$. Therefore, we can observe or either decline in production or not very significant growth, which has quite clear reasons related to the system crisis of economy of the Russian Federation. 
As the key issues of import substitution in the agro-industrial complex, Russian experts point out the low investment activity and attractiveness (investors have uncertainty about duration of the embargo), lag in technology, underdeveloped infrastructure, low diversification, lack of effective competition in the domestic market, insufficient level of financial stability of goods producers and low efficiency of market regulation in the field of the agro-industrial complex ${ }^{59}$.

Answering the second question about what should have been done (instead of banning the import of high-quality European and American foodstuffs) to ensure food security of Russia, we note that such measures could include enhancement of land improvement ${ }^{60}$, restoration of disturbed lands ${ }^{6}$, correction of the civil legislation making it difficult to take into account the risk-related and seasonal nature of contractual relations with agricultural goods producers ${ }^{62}$. Moreover, among these measures, we should point out tax mitigation, availability of credits, marketing possibility, holding back the factors that can destabilize the situation (fight against monopolies, fight against crime) ${ }^{63}$, creating a favorable climate for investments and innovations, constant modernization of production, raising the professional level of rural workers $^{64}$, estimating environmental costs of agricultural production and taking measures to protect land, water and soil (which will allow exercising both the right to food and a healthy environment) ${ }^{65}$. Along with the abovementioned recognized measures to ensure food security, it is necessary to use also the possibilities provided to us by science and technology of the $2 \mathrm{I}^{\text {st }}$ century, in particular, to use biotechnologies (including GMOs), nanotechnologies in agricultural production more widely, as well as to develop a legal mechanism of consideration of food needs of socially vulnerable groups of population, including women, children and indigenous small-numbered peoples. Exactly these measures are necessary to ensure sustainability and food security of Russia.

A number of measures implemented by the Government of the Russian Federation deserve approval and support, including development of digital technologies in agriculture, provision of agricultural goods producers with budget financing (subsidies) from the state on a repayable and non-repayable basis, and development of the system of reserves. Therefore, without changing the available model of the Russian economy there is no point in expecting some or other qualitative changes in the area of ensuring food security.
Aleksey Pavlovich

Anisimov

Nina

Vladimirovna

Mirina

Anatoliy

Jakovlevich

Ryzhenkov 


\section{Conclusion}

Food security of a country is a component of national security characterizing the degree of exercise of the human right to food in the country and achievement of goals of sustainable development, guar-

CEJISS anteeing physical and economic availability of high-quality and safe I/2020 foodstuffs for citizens, in the amount necessary for a healthy diet.

Advantages of this definition consist in consideration of international recommendations as well as avoidance of narrow economic perception of the goals and objectives of ensuring food security in the Russian Federation or another country. Ensuring food security is a strategic social and economic goal for any state. When solving this task in Russia, it is necessary to clearly distinguish between "food security" and "food independence". While the first category characterizes the degree of provision of population with quantitative and qualitative foodstuffs, their physical and economic availability and safety, within the framework of the second one, the emphasis is placed on "import substitution", that is a percentage between goods produced in the country and imported ones. In the Russian Federation, the main emphasis of public authorities is placed on ensuring food independence to the prejudice of goals and objectives of ensuring food security. In our opinion, availability of imported foodstuffs itself does not pose a particular threat to national security (a much greater threat comes from systemic corruption, poverty, bureaucracy or the destruction of ecological systems). When determining priorities, it is necessary to rely on provisions of Article 2 of the Constitution of the Russian Federation, according to which recognition and protection of human rights is a duty of the state. This is why the authorities need to rely on the priority of the human right to food but not on the desire to take revenge on the EU countries or the USA for the sanctions imposed in 2014, limiting the rights of Russian citizens to consumption of high-quality foodstuffs from the leading countries of the world. The artificial restriction of the competitive environment led to entry of the products in the Russian food market that could not have appeared there before in the competitive environment. This led to deterioration of the quality of foodstuffs and an increase in their price. Thus, lifting of food sanctions imposed by the President of the Russian Federation as soon as possible is in the interests of the Russian population, these sanctions have reduced the level of guarantees of human rights in Russia. 
Undoubtedly, one of the priorities of the food policy in Russia must be development of agriculture, which will be possible in case of changes in the credit and tax policies, ensuring the rule of law and justice, increasing guarantees of rights of owners and tenants of agricultural lands, improving the environmental situation in the country. Most of the other measures taken in Russia today by the state to ensure physical and economic availability of food for population, create strategic reserves, develop transport and trade networks, food quality standards, etc. do not cause any objections and deserve full approval and support. Food security is one of the guarantees of sustainable development of agriculture, it is located at the junction of three types of national security: economic, social and environmental. This balance must not be disrupted, just like for ensuring sustainable development. Russia has to take more part in international division of labor exporting some types of foodstuffs (wheat) and purchasing other ones (fruit, meat), without politicizing trade and economic relations. Ensuring food security can be achieved only by economic methods, which will allow creating conditions for development of the national agrarian sector through successful competition of rural goods producers, with the understanding that this task can be solved only due to the efforts of the entire international community.

In order to achieve food security at the international and national levels, it is necessary to revise the existing negative attitude towards agricultural goods produced using biotechnologies (GMOs), as well as to develop a system of measures that takes into account the effects of climate change. At the moment, GMOs are completely prohibited in the Russian Federation, and the climate is not an object of environmental legal protection. Special mention should be made of the need for consideration of the UN recommendations by the Russian Federation in terms of measures of food protection regarding the interests of vulnerable groups of population.

\section{$\lesssim$}

Anisimov Aleksey Pavlovich is affiliated to the Faculty of management and law, Kalmyk State University, Russia, Republic of Kalmykia, Elista, and may be reached at anisimovap@mail.ru.
Food Security in the Post-Soviet Space 
Nina Vladimirovna Mirina is affiliated with the Department of Entrepreneurship and Consumer Market Development of the Directorate of Economic Development and Investments of the Apparatus of the Head of and may be reached at e-mail: nina_mirina@mail.ru.

CEJISS

I/2020 Anatoliy Jakovlevich Ryzhenkov is affiliated with the Department of Civil Law and Procedure, Kalmyk State University, and may be reached at e-mail: 4077778@list.ru.

\section{Endnotes}

I Cook K. (2010), 'The right to food and the environment', Environmental Law Review I2, p. 3-4.

2 Wolbring G., Mackay R. (2014), 'Analysis of Newspaper Coverage of Food Security through a Disability Studies Lens', Journal of Sustainable Development 7-4, p. 2-4.

3 Undoubtedly, this issue existed also before. Some Russian researchers refer emergence of the category "food security" to the times of Kievan Rus (9-Ioth centuries). Ref.: Belkharoev Kh.U. (20II), 'Genesis of legal support of food security of Ancient Russia', Gaps in the Russian legislation 3, p. 268-270 (Белхароев Х.У. (2011), 'Генезис правового обеспечения продовольственной безопасности Древней Руси', Пробелы в российском законодательстве 3, С. 268-270). In our view, this approach is a big exaggeration.

4 Kuzin V.N. (2010), 'Food security: theory and practice of the issue', Bulletin of Saratov State Academy of Law 2, p. 39-43 (Кузин В.Н. (2ого), 'Продовольственная безопасность: теория и практика проблемы', Вестник Саратовской государственной академии права 2, С.39-43).

5 UN General Assembly Resolution of December 19, 2017, "The right to food".

6 UN General Assembly Resolution of December 20, 20I7, "Protection of global climate for present and future generations of mankind".

7 UN General Assembly Resolution of September 25, 20I5, "Transforming our world: the 2030 Agenda for Sustainable Development".

8 Ayanbaev E.S. (20I7), Regime of pesticides in modern international law (PhD thesis, Al-Farabi Kazakh National University) (Аянбаев Е.С. (20I7), Режим пестицидов в современном международном праве (диссертация доктора философии (PhD) по специальности 6Do30200 - Международное право, Алматы, Казахский национальный университет).

9 Kuzin V.N. (2010), 'State food reserves in the context of the food security issue', Business in law 2, p. 7 (Кузин В.Н. (2010), 'Государственные продовольственные резервы в контексте проблемы продовольственной безопасности', Бизнес в законе 2, С.7).

Io Chernova O.A. (20II), 'Issues of regulatory support of national interests of the Russian Federation in the food area', available at: <http://rusnauka. com/Page_ru.htm> (access date o6.or.20I9) (Чернова О.А. 'Проблемы 
нормативно-правового обеспечения национальных интересов Российской Федерации в продовольственной сфере')

II Moiseenkov A.V. (2002) Food security of Russia as a social and demographic issue (in terms of rural population of the Russian Federation) (Candidate thesis, Institute of social and political studies of the Russian Academy of Sciences) (Моисеенков А.В. (2002), Продовольственная безопасность России как социально-демографическая проблема (на примере сельского населения Российской Федерации) (автореферат диссертации кандидата экономических наук, Москва, Институт социально-политических исследований Российской академии наук)

I2 Fromherz N.A. (2012), 'The Case for a Global Treaty on Soil Conservation, Sustainable Farming, and the Preservation of Agrarian Culture', Ecology Law Quarterly 39, p. 57-I2I.

I3 Sternick A. (2012), 'Food Fight: The Impending Agricultural Crisis and a Reasonable Response to Price Volatility', Villanova Environmental Law Journal 23-I, p. I59-I60.

I4 Lomakin P.N. (20I7), Ensuring legal security of Russia: domestic and international aspects (Candidate thesis, Moscow state Institute of international relations) (Ломакин П.Н. (2017), Обеспечение продовольственной безопасности России: внутренние и международные аспекты (автореферат диссертации кандидата экономических наук, Москва, Московский государственный институт международных отношений).

I5 Demyanenko V.V.(2006), 'Food security as the most pressing issue of modern Russia', Bulletin of Saratov State Academy of Law 3, p. 88 (Демьяненко В.В. (2006), 'Продовольственная безопасность - самая острая проблема современной России', Вестник Саратовской государственной академии права 3, С. 88.

I6 Petryakov V.G., Faizullin G.G. (2005), 'Role of state and law in ensuring food security of Russia', New Legal Thought 5, p. 33-34 (Петряков В.Г., Файзуллин Г.Г. (2005), 'О роли государства и права в обеспечении продовольственной безопасности России', Новая правовая мысль 5, С.3334 .

I7 Reid M.S. (2002) 'Agriculture and the environment - building a sustainable and healthy future', Environs 25-2, p. 55-58.

I8 Peters K.A. (20I0), 'Creating a Sustainable Urban Agriculture', Journal Environmental Law and Litigation 25, p. 205-2II.

I9 Shatravka A.S. (20II), Enhancement of the food security system of the Russian Federation (Candidate thesis, Moscow Academy of Economics and law) (Шатравка А.С. (20II), Совершенствование системы обеспечения продовольственной безопасности Российской Федерации (автореферат диссертации кандидата экономических наук, Москва, Московская академия экономики и права).

20 Malkhasyan A.V. (2014), Agrarian legal issues in the field of ensuring food security (Candidate thesis, Moscow State Law University) (Малхасян А.В. (2014), Аграрно-правовые проблемы в сфере обеспечения продовольственной безопасности (автореферат диссертации кандидата юридических наук.).

2I Valetova Yu.A. (2013), International legal support of food security (Candidate thesis, Moscow State Law Academy) (Валетова Ю.А. (2013), Международно-правовое обеспечение продовольственной безопасности 
(автореферат диссертации кандидата юридических наук, Москва, Московская государственная юридическая академия).

22 Czarnezki J.J. (20II), 'Food, Law \& the environment: informational and structural changes for a sustainable food system', Utah Environmental Law Review 3I-2, p. 265-266. (Candidate thesis, Russian presidential Academy of public administration) (Белхароев Х.У. (2003), Правовое обеспечение продовольственной безопасности современной России (автореферат диссертации кандидата юридических наук, Москва, Российская академия государственной службы при Президенте РФ).

24 Deineka L.N. (2004), 'Food security as a systemic issue of globalized economy', Taganrog State University of Radioengineering Review 4, p. 75 (Дейнека Л.Н. (2004), 'Продовольственная безопасность - системная проблема глобализируемой экономики', Известия ТРТУ 4, С.75).

25 Dadalko V.A. (2013), 'Food security as a component of national and economic security of the state', Bulletin of Ufa State Aviation Technical University I7-7, p. 2I (Дадалко В.А. (2013), 'Продовольственная безопасность как составляющая национальной и экономической безопасности государства', Вестник Уфимского государственного авиационного технического университета Том I7. № 7. С.2I).

26 Ayanbaev E.S. (20I7), Regime of pesticides in modern international law $(\mathrm{PhD}$ thesis, Al-Farabi Kazakh National University) (Аянбаев Е.C. (2017), Режим пестицидов в современном международном праве (диссертация доктора философии $(\mathrm{PhD})$ по специальности 6Do30200 - Международное право, Алматы, Казахский национальный университет).

27 Agarkov A.V. (20I0), 'Food security in the system of economic security of Russia', Bulletin of Stavropol State University 5, p. Іо5 (Агарков А.В. (20Iо), 'Продовольственная безопасность в системе экономической безопасности России', Вестник Ставропольского государственного университета 5 , С.Іо5).

28 Matyuk L.V. (2008), 'Basis of food security of Kamchatka Krai: issues and solutions', Power and administration in the Russian East 2, p. 57-64 (Матюк Л.В. (2008), 'Основа продовольственной безопасности Камчатского края: проблемы и пути решения’, Власть и управление на Востоке России 2, С. 57-64).

29 Boklan D.S. (2016), Interaction of international environmental and international economic law (Doctor thesis, Moscow state Institute of international relations) (Боклан Д.С. (2016), Взаимодействие международного экологического и международного экономического права (диссертация доктора юридических наук, Москва, Московский государственный институт международных отношений).

30 Vershilo N.D. (2008), Environmental legal fundamentals of sustainable development (Doctor thesis, Institute of state and law of the Russian Academy of Sciences) (Вершило Н.Д. (2008), Эколого-правовые основы устойчивого развития (автореферат диссертации доктора юридических наук, Москва, Институт государства и права РАН).

3I Brown C. (20I0), 'A Litigious Proposal: A Citizen's Duty to Challenge Climate Change, Lessons from Recent Federal Standing Analysis, and Possible State-Level Remedies Private Citizens Can Pursue', Journal of Environmental Law and Litigation 25, p. 39I-395. 
32 Seminikhina V.A. (20I0), Legal regulation of climate protection: comparative legal analysis (Candidate thesis, Institute of state and law of the Russian Academy of Sciences) (Семинихина B.A. (2ого), Правовое регулирование охраны климата: сравнительно-правовой анализ (автореферат диссертации кандидата юридических наук, Москва, Институт государства и права РАН).

33 Oberthür S. (20I6), 'Where to go from Paris? The European Union in climate geopolitics', Global Affairs 2-2, p. II9-I30.

34 Gonzalez C.G. (2012), 'The Global Food System, Environmental Protection, and Human Rights', Natural Resources and Environment 26, p. 7.

35 Birdsong B.C. (20I3), "From "Food Miles" to "Moneyball": How We Should Be Thinking About Food and Climate', Maine Law Review 65-2, p. 4I2-4I3.

36 Ref. par. 8 of the Rome Declaration on Nutrition adopted as a result of the Second International Conference on Nutrition (Rome, November I92I, 20I4), available at: <http://www.fao.org/3/a-ml542r.pdf> (access date 7.0I.20I9)

37 Ref. par.I of the UN General Assembly Resolution of December 20, 2017, "Protection of global climate for present and future generations of mankind", available at: <http://www.un.org/ru/ga/72/docs/72res3. shtml $>$,(access date 07.0I.2019).

38 Ref. par.I3 of the UN General Assembly Resolution of December 20, 2017, "Agriculture development, food security and nutrition", available at: <http://www.un.org/ru/ga/72/docs/72res3.shtml>, (access date 07.0I.20I9).

39 Garcia L.G. (2015), "Free the Land": A Call for Local Governments to Address Climate-Induced Food Insecurity in Environmental Justice Communities', William Mitchell Law Review 4I-2, p. 573-6I7.

40 Jaffe J. (20II), 'The Political Question Doctrine: An Update in Response to Recent Case Law', Ecology Law Quarterly 38, p. I035.

4I Boutrous T.J., Lanza D. (2008), 'Global Warming Tort Litigation: The Real "Public Nuisance", Ecology Law Currents 35, p. 82-87.

42 Parker-Flynn J.E. (20I4), 'The Intersection of Mitigation and Adaptation in Climate Law and Policy', University of California, Davis 38, p. 6-9.

43 How to feed population of the world in 2050, available at: <http:// docplayer.ru/38844I49-Kak-prokormit-naselenie-mira-v-2050-godu. html $>$ (access date 07.0I.20I9).

44 Pollans M.J. (2015), 'Regulating Farming: Balancing Food Safety and Environmental Protection in A Cooperative Governance Regime', Wake Forest Law Review 50, p. 407.

45 Sobolev N.S. (20II), Food security as a social economic factor of ensuring health of Russians (Candidate thesis, Saratov State University named after N. G. Chernyshevsky) (Соболев Н.С. (2оII), Продовольственная безопасность как социально-экономический фактор обеспечения здоровья россиян (автореферат диссертации кандидата экономических наук, Саратов, Саратовский государственный университет имени Н.Г. Чернышевского).

46 Ganenko I. Top 25 products we import. Russia is fed for $\$ 23$ billion <https:// www.agroinvestor.ru/rating/article/30319-top-25-produktov-kotorye-myimportiruem/> (access date 20.03.2019).

47 Vedysheva N.O. (2008), 'Legal issues of ensuring food security of the Russian Federation', Gaps in the Russian legislation I, p. I75 (Ведышева Н.О. (2008), 'Правовые проблемы обеспечения
Food Security in the Post-Soviet Space 
продовольственной безопасности РФ', Пробелы в российском законодательстве I, C.I75).

48 Kobylkin R.A., Medvedeva L.M. (2016), 'Food security as a component of national security: philosophical and cultorological aspects', Bulletin of Volgograd Academy of the MIA of Russia 3, p. I55-159 (Кобылкин Р.А.,

CEJISS Медведева Л.М. (2ог6), 'Продовольственная безопасность как элемент I/2020 национальной безопасности: философские и культурологические аспекты', Вестник Волгоградской академии МВД России 3, С. I55-I59).

49 Steier G. (2017), 'A Window of Opportunity for GMO Regulation: Achieving Food Integrity Through Capand-Trade Models from Climate Policy for GMO Regulation', Pace Environmental Law Review 34, p. 305-306.

50 Ruling of the Supreme Court of the Russian Federation of November II, 2015 in case No. AKPII51007, available at: <https://www.zakonrf.info/ suddoc/9ac38ea79Ib67fa3f57aoaaoirf457eb/> (access date Io.or.20I9).

5I Kireeva N.A., Saninsky S.A. (2017), 'Food security of a region in the context of the import substitution policy', Information security of regions 2, p. I6 (Киреева Н.А., Санинский С.А. (2017), 'Продовольственная безопасность региона в контексте политики импортозамещения', Информационная безопасность регионов 2, С.I6).

52 More than half of food in Russia is counterfeit often harmful to health / Более половины продовольствия в России - фальсификат, нередко вредный для здоровья (20I8) // <https://newrezume.org/news/20I8-II-0930522?utm_source=copypast $>$ (access date 20.03.2019).

53 Lomakin P.N. (2017), Ensuring food security of Russia: domestic and international aspects (Candidate thesis, Moscow state Institute of international relations) (Ломакин П.Н. (2017), Обеспечение продовольственной безопасности России: внутренние и международные аспекты (автореферат диссертации кандидата экономических наук., Москва, Московский государственный институт международных отношений).

54 Gaiva E. (2019) 'Cheese falls out. Why palm oil import rises by a quarter', Rossiyskaya Gazeta. January 3І (Гайва Е. (2019) 'Сыр выпал. Почему импорт пальмового масла вырос на четверть', Российская газета. 3I января <https://rg.ru/20I9/oI/3I/pochemu-vyros-import-palmovogomasla-v-rossiiu.html> (access date 20.03.2019).

55 Harm of palm oil to human health. Вред пальмового масла для здоровья человека (2019) <https://www.oum.ru/literature/zdorovje/vred-palmovogomasla-dlya-zdorovya-cheloveka/> (access date 20.03.2019).

56 Tikhonyuk N.E., Kotegova L.A., Telegina T.O. (20I8), 'Food security and the forecast of agricultural development in Russia', Proceedings 2, p. 84 (Тихонюк Н.Е., Котегова Л.А., Телегина Т.О. (2018), 'Продовольственная безопасность и прогноз развития сельского хозяйства в России', Ученые записки 2, С.84).

57 Federal State Statistics Service. Indices characterizing import substitution in Russia, available at: <http://www.gks.ru/wps/wcm/connect/rosstat_ main/rosstat/ru/statistics/importexchange/\# > (access date Io.oI.20I9).

58 Ibid.

59 Lomakin P.N. (2017), Ensuring food security of Russia: domestic and international aspects aspects (Candidate thesis, Moscow state Institute of international relations) (Ломакин П.Н. (20I7), Обеспечение продовольственной безопасности России: внутренние и международные 
аспекты (автореферат диссертации кандидата экономических наук., Москва, Московский государственный институт международных отношений).

6o Pysheva E.S. (20I5), Legal regulation of land improvement (Candidate thesis, Institute of legislation and comparative law Russian Federation government) (Пышьева Е.С. (2015), Правовое регулирование мелиорации земель (автореферат диссертации кандидата юридических наук, Москва, Институт законодательства и сравнительного правоведения при Правительстве РФ).

6I Selivanova K.A. (20I7), 'Ensuring food security of the country through elements of the environmental legal mechanism', New legal thought I, p. 67-69 (Селиванова К.А. (2017), 'Обеспечение продовольственной безопасности страны через элементы эколого-правового механизма', Новая правовая мысль, г, С.67-69).

62 Popova O.V. (2009), Legal regulation of credits for agricultural goods producers (Candidate thesis, Institute of state and law of the Russian Academy of Sciences) (Попова О.В. (2009), Правовое регулирование кредитования сельскохозяйственных товаропроизводителей (автореферат диссертации кандидата юридических наук, Москва, Институт государства и права РАН).

63 Guzieva E.V., Khutyz Z.M., Vukovich G.G.(2015), 'Food security in the system of international economic security: issues and their solutions', Economy of sustainable development 3, р. ІІ (Гузиева Е.В., Хутыз 3.М., Вукович Г.Г. (2015), 'Продовольственная безопасность в системе международной экономической безопасности: проблемы и пути их решения', Экономика устойчивого развития 3, С.III).

64 Staley K. (20I0-20II), 'Kentucky's Food Democracy: A Comparison of Local Food Policies of Four Appalachian Tobacco-Growing States', Journal of Animal and Environmental Law 2, p. IOо-ІоІ.

65 Telesetsky A. (20I6), 'Fulfilling the Human Right to Food and a Healthy Environment: Is It Time for an Agroecological and Aquaecological Revolution?' Vermont Law Review 40, p. 796-797. 